\title{
DIMENSÃO UTÓPICA NAS REPRESENTAÇÕES SOBRE O ENSINO DE HISTÓRIA: MEMÓRIAS DE PROFESSORES
}

\author{
Antonio Simplício de Almeida Neto*
}

\begin{abstract}
Es cierto que la desesperación, momento de la acción poiética, difiere de la angustia, ese vacío del cual no se sale. Quienes rechazan el riesgo porque no quieren sufrir ya no quieren la alegría. (Henri Lefebvre)
\end{abstract}

RESUMO: Esse artigo trata das representações de professores de História acerca da dimensão utópica em sua disciplina, ou seja, a maneira como representam certa concepção prospectiva ao lecionarem uma disciplina escolar que lida com o passado. Consideramos que a educação tem como pressuposto uma visão projetiva, uma vez que supõe uma perspectiva de homem, sociedade e mundo no ato educativo, e o ensino de História, mais especificamente, por ser uma disciplina que lida com as transformações temporais e com temas eminentemente políticos e sociais, inserindo o homem neste processo. Situamos a discussão atual acerca do tema no ensino de História, inserido no debate da crise da modernidade e postulados pós-modernistas, a oscilar entre uma postura de pensar a disciplina como inexorável instrumento de transformação sócio-política ou vã ilusão prospectiva. Visando uma melhor compreensão da questão proposta, valemo-nos da análise de relatos orais obtidos através de entrevistas com professores da disciplina, que lecionaram nos anos de 1960/70 e 1980/ 90, tendo por perspectiva a teoria crítica das representações de Henri Lefebvre e o debate sobre memória e história oral.

Palavras-chave: Ensino de História. Utopia. Representação. Memória. História oral.

Doutor em Educação e professor do Centro de Educação e Ciências Humanas da Universidade Federal de São Carlos (UfSCAR).E-mail: toninhosaneto@uol.com.br 
Dimensão utópica nas representações sobre o ensino de História...

UTOPIAN DIMENSION IN THE REPRESENTATIONS ON HISTORY TEACHING: MEMORIES OF TEACHERS

ABSTRACT: This paper explores the representations of History teachers on the utopian dimension in their discipline, that is, how they represent a certain prospective conception when teaching a school discipline dealing with the past. We consider that education has assumed a projective vision, since it supposes the perspective of man, society and world in the educative act. This is even more the case with History teaching, since it is one of the disciplines that eminently deals with the secular transformations and social and political subjects, inserting man in this process. We locate the current discussion on the subject in History teaching, inserted in the debate of the crisis of modernity and post-modern postulates, oscillating between the stance of thinking this discipline as an inexorable instrument of social political transformation or a vain prospective illusion. To better understand the proposed issue, we analyze verbal stories from interviews with professors of this discipline who have taught in the 60s-70s and in the $80 \mathrm{~s}-90 \mathrm{~s}$, under the perspective of Henri Lefebvre's critical theory of representations and the debate on memory and oral history.

Key words: History teaching. Utopia. Representation. Memory. Oral history.

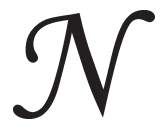

o conhecido texto "Sobre o conceito da história", escrito em 1940, Benjamin (1986) faz uma bela e assombrosa análise do quadro Angelus Novus, de Paul Klee, o "anjo da história": uma figura de olhar catatônico, pasmado, asas estendidas, é impelida para o futuro ao mesmo tempo em que observa o passado, suas catástrofes e ruínas. Esse anjo gostaria de "deter-se para acordar os mortos e juntar os fragmentos" (p. 226), mas não pode, pois a tempestade - o progresso que sopra do paraíso o impede de fechar as asas. Perplexidade e desolação rondam seu olhar, a angústia mobiliza um desejo lancinante de transformação.

No debate sobre o ensino de História, ${ }^{1}$ nas últimas décadas, essa interpretação benjaminiana serviria como epítome, pois ilustra bem a condição de seus professores, a angústia de seu olhar sobre o passado, a observação dos despojos, a vontade de reconstrução, o medo da repetição dos "erros", o desejo de intervir na transformação. Falamos de uma espécie de Angelus Novus do ensino, um arauto do passado que espera 
que seus ensinamentos promovam, se não a reconstituição dos fragmentos, ao menos um porvir com menos ruínas.

Essa concepção dá sinais de esgotamento, pelo simples fato de ter sido erigida de maneira frágil, quando se supunha portentosa. Laville (1999, p. 127), em artigo que propõe desanuviar as ilusões em torno do ensino de História, aponta como um grande equívoco “(...) se acreditar que, pela manipulação dos conteúdos, é possível dirigir as consciências ou as memórias, quando a experiência do presente século mostra que está longe de ser tão certo assim quanto tantos parecem acreditar, o que provavelmente não passa de uma grande ilusão". Essa crença de que através do ensino de História seria possível regular consciências e comportamentos, aglutinar descontentamentos e decepçóes, catalisar movimentos de transformação, é, para o autor, apenas e tão somente uma vã ilusão. No entanto, tem mobilizado esforços e paixões.

Mas esse arranjo pode ser pensado de outra maneira. Retornando à interpretação de Benjamin sobre o quadro de Klee, numa não menos instigante análise, Sevcenko (1993, p. 49-50) propõe:

O anjo da história é assim um anjo decaído e sua rebeldia o tornou impotente para auxiliar os vencidos, mortos e humilhados. Não estando mais sintonizado com o poder, ele próprio está condenado a ser um vencido e um enxovalhado. Sua natureza de ser destinado à vida eterna o submete ao castigo de assistir paralisado, ele, cuja missão precípua é agir e salvar, à destruição do mundo e à degradação de si mesmo.

O que se apresentava como possibilidade, promessa e propósito transmuta-se em paralisação, frustração e imobilismo. Para esse autor, Benjamin e Klee vaticinaram o fim da modernidade e sua crença no progresso e na "utopia da igualdade perfeita, produzida pela razão, governada pela técnica e desfrutada pela arte" (idem, ibid., p. 47), representando aqueles que, aturdidos, “(...) não estão mais voltados para o infinito radiante do futuro e sim para a tragédia impronunciável do passado. Não acreditam mais no absoluto, nem se deixam levar por suas falsas promessas. Estão sós, reduzidos aos limites estreitos de sua fraqueza, seu horror e sua fúria” (p. 50).

Repensando aquele Angelus Novus do ensino, prenhe de desejos de mudança face à crise tão alardeada existente na educação, nos deparamos com um professor de História impotente diante das impossibilidades, seu olhar para o passado adquire ares de nostalgia, suas tentativas 
Dimensão utópica nas representações sobre o ensino de História...

de juntar os fragmentos resultam inúteis, seu projeto prospectivo soa anacrônico.

As discussões sobre as quais me deterei ${ }^{2}$ referem-se à dimensão "utópica" presente no ensino de História. Via de regra, o ensino dessa disciplina tem, por décadas, trabalhado com uma virtual capacidade de, através de um resgate pretensamente crítico do passado, apostar numa transformação positiva e projetar um novo futuro.

Em tempos de transformações significativas como a que vimos atravessando nas últimas décadas, particularmente no Brasil, os anseios por mudanças promissoras são proporcionais às angústias geradas pela falta de soluçóes e respostas a problemas sociais, econômicos e políticos. Não poderia ser diferente na educação, já que é inerente às atividades do professor o ato de operar com projeçóes, uma vez que prevê um fim a atingir com seus alunos, seja de ampliação do conhecimento, seja de formação de valores.

No ensino de História, tal questão se faz sentir com maior evidência, pois que os professores lidam com o tempo passado e, dessa maneira, têm como matéria-prima uma vastidão de temas intrincados com suas variantes e contradiçóes a serem exploradas e explicadas, podendo dar algum sentido e significado ao presente e, inevitavelmente, serem lançados nas projeções do ato educativo, considerando que os ensinamentos dessa disciplina seriam capazes de contribuir para uma sociedade melhor que a passada e aquela que se está vivendo. Alguns temas habitualmente abordados pela disciplina, como poder, relações de classe, revoluções, guerras, regimes políticos, movimentos sociais, concorrem para esta visão da história como provedora de lições do passado a serem aprendidas pelo presente.

Considerando, então, que essa dimensão utópica presente no ensino de História tem mobilizado açôes concretas, influenciado pessoas e levado a novos projetos, como tratá-la como mero devaneio, coisa falsa? Como poderia uma vã ilusão possuir tanta força?

Ocorre que essa dimensão utópica não se constitui como um todo coerente, dotado de sentido único. As referências a essa concepção, presentes no ensino de História, variam desde as posturas marcadamente revolucionárias até posicionamentos mais diluídos, mal definidos e, eventualmente, atrelados a uma estratégia de marketing, haja vista como algumas editoras apressam-se em incorporar aos antigos e 
novos livros o adjetivo "crítica", conduzindo a utopia ao sabor do mercado. Verifica-se, ainda, um desejo de construir novas utopias, como se algumas antigas bandeiras empunhadas no passado não mais servissem diante das novas problemáticas socioeconômicas que estão postas. Por outro lado, é de se observar a existência de discursos utópicos elaborados em períodos diferentes e que se assemelham.

Diante desse quadro, alguns questionamentos são concernentes: Como se originam esses discursos utópicos no ensino de História? Essas utopias pautam-se na realidade? O que falam de seu período? Quais fatores interferem na formação e transformação dessa dimensão utópica? Como agem esses elementos, acirrando ou drenando o desejo de mudança? Possuem anacronismos? Essa dimensão utópica é apenas uma ilusão? Quais seus efeitos na prática de sala de aula? Apresentam contradiçôes? Como os professores percebem essa dimensão utópica em sua disciplina e prática cotidiana?

Considero que o ensino de História não possa ser tratado como equação de fáceis resolução e resultado, já que, com o desvelar de suas intenções e práticas, distingui-se um verdadeiro emaranhado de questôes que envolvem a disciplina, podendo, algumas dessas, levar a grandes e desastrosos equívocos relativos a concepção da área e suas reais possibilidades, tornando o seu ensino inócuo, quando não danoso para o aluno.

O entendimento dos questionamentos propostos pode contribuir para um melhor esquadrinhamento do ensino de História nas últimas décadas e, mais especificamente, uma análise de sua dimensão utópica, aspecto que vem sendo debatido com razoável intensidade na educação de modo geral, mas de modo insuficiente nessa disciplina que, no entanto, tradicionalmente ambiciona "acordar os mortos e juntar os fragmentos".

A proposição de discutir a noção de utopia presente no ensino de História necessita de um suporte teórico que se adeque à inerência sólida e fluida, permanente e transitória, mobilizadora e paralisante, presente e ausente da temática. A teoria crítica das representações apresentada por Lefebvre (1983) busca resolver o impasse imobilizador - referente ao suposto caráter ilusório ou verdadeiro da referida dimensão - que nos impede de aprofundar a análise tanto das vivências concretas, como das concepçôes que sobre elas são formadas. 
Dimensão utópica nas representações sobre o ensino de História...

Sobre o dilema envolto na questão, ele afirma que “(...) las representaciones no son ni falsas ni verdaderas, sino a la vez falsas o verdaderas: verdaderas como respuestas a problemas 'reales' y falsas como disimuladoras de las finalidades 'reales'” (1983, p. 62).

Deve-se, então, compreender as representações sem a pretensão de rechaçá-las, entendendo os processos pelos quais se formam, ganham força, circulam e deslocam o representado, sobreposto por seu representante através da representação. Lefebvre propõe que aquilo que se representa está presente e ausente na representação, que medeia essas duas ocorrências não excludentes, faces de uma mesma condição em existência mútua.

Somente através da análise poderemos escapar das representações enganosas que ocorrem nos processos de representação e que são sua força, resultando em simulacros, repetições e situaçōes miméticas. Sintetizando esta noção em Lefebvre, Lutfi (1996, p. 96) afirma que o

(...) papel da teoria crítica das representações não é destruí-las, pois não é possível viver e compreender uma situação sem representá-la. A filosofia, tradicionalmente, quer eliminar as representações. Sem elas, entretanto, só restam a morte e o nada. A teoria deve expor o poder da representação no mundo contemporâneo, deslindar os mecanismos de sua produção e permanência, e ao fazê-lo, anunciar "um pensamento novo e ativo já em marcha”.

Para Lefebvre, as representações formam-se no cotidiano, entendido como um nível da realidade social onde ocorrem a construção e transformação da sociedade, sendo que o desvelamento desse nível é a chave para a compreensão das representaçôes. Estas se constituem como resultado das formulações teóricas - o concebido - e das experiências da vida social e prática, no plano individual e coletivo - o vivido. Dessa maneira, as representaçôes apresentam-se como manifestaçôes da relação do concebido com a vivência, emergindo da consciência individual e da correlação com as condições históricas particulares e gerais. São, portanto, fruto do ser individual e social. Assim, entende-se que a representação é inerente ao viver e sua compreensão.

No entanto, se é no cotidiano que se formam as representações capazes de dissimular o vivido, é aí que se formulam as críticas, também na forma de representaçóes, que combatem a homogeneidade e a unidade pretendidas pelas representaçôes hegemônicas. Isso significa 
dizer que o cotidiano contém tanto as representações enganosas, que encobrem questôes relevantes, como aquelas que apontam para o porvir, a utopia. Não as utopias abstratas, que ele trata de atacar, mas a utopia do possível, manifesta no descontentamento e no desejo de transformação. É no cotidiano que se encontra, portanto, tanto a dissimulação como o gérmen da mudança.

A busca desse entendimento, para Lefebvre (1983), deve levar em conta o concebido (saber, ciências, conceitos teóricos) e o vivido (corpo, subjetividade, vivência social e coletiva). Pensando-as socialmente, as representações formam-se da maneira como os grupos são e como se vêem, como atuam e como pensam sua atuação, como sofrem e sonham o porvir. Para o autor, as “(...) representaciones no son simples hechos, ni resultados comprensibles por su causa ni simples efectos. Son hechos de palabra (o si prefiere de discurso) y de práctica social" (p. 94-95).

Pensar a utopia no ensino de História, tendo como referência a teoria crítica das representações, redimensiona a questão em novas possibilidades, para além da visão limitadora e simplificadora do certo/errado, existe/não existe, falso/verdadeiro, de modo a compreendermos seu poder motivador e inibidor, clarificador e mistificador, presente nas atividades que envolvem a ação escolar.

A proposta de discutir uma disciplina escolar em sua dimensão utópica encontrou, no recurso do relato oral, uma necessária e importante fonte documental para a recuperação de aspectos do cotidiano escolar e a investigação das representações acerca do ensino de História, pelo olhar dos professores dessa disciplina.

O relato oral se apresenta como uma espécie de tecido puído, no qual se vai cerzindo sutil e silenciosamente. $\mathrm{O}$ olhar para essa trama, que se gasta e constitui ao mesmo tempo, requer uma abordagem cautelosa e criteriosa, uma vez que possui evidentes limitaçóes e imprecisões a serem vistas não como impeditivos ou fraquezas, mas como especificidades a serem estudadas e tornadas assertivas.

A utilização dessa fonte documental tem recebido, nas últimas décadas, importante aporte teórico e metodológico por meio de publicaçôes, encontros de especialistas e debates que dissiparam muitos dos questionamentos que recaíam sobre as supostas precariedades dos relatos orais e da fragilidade da memória. Entendo haver consenso de que 
Dimensão utópica nas representações sobre o ensino de História...

essa questão esteja superada, uma vez que qualquer fonte documental utilizada pelo pesquisador está sujeita a imprecisões e limitaçōes, foi produzida em determinado contexto histórico-social envolvendo subjetividades, pressões, crenças, interesses. Para Pollak (1992), o fundamental é o rigor crítico que deve ser aplicado pelo pesquisador na coleta, seleção e análise das fontes, seja qual for seu tipo.

Alguns aspectos desse debate referente ao uso de relatos e seu suporte, a memória, podem ser indicados:

a) O relato não é a experiência, mas o que a memória fez dela (Hall, 1992), pois implica seleção, (re) interpretação, (re) leitura, (re) avaliação de fatos do passado;

b) ao rememorar o passado, busca-se atribuir um sentido para a própria vida, para as relações familiares e sociais, o desenvolvimento da vida profissional, as escolhas e posicionamentos (Janotti \& Rosa, 1992/1993);

c) mais que um simples mecanismo de produzir lembranças, a memória é o que possibilita estarmos no mundo, situados nos grupos sociais, estabelecendo relações, num "processo ativo de criação de significações” e re-significações (Portelli, 1997a, p. 33), reavaliado em função dos acontecimentos do presente (Portelli, 1997b; Soares, 1991);

d) sob certo aspecto, o relato oral se apresenta como uma lembrança preconcebida (Hall, 1992), como um pacote pronto com os fatos do passado devidamente ajustados a uma versão mais conveniente e confortável para o depoente;

e) alguns relatos se constituem como busca de justificação e valorização da história pessoal e do grupo ao qual se pertence, um "sentimento de identidade (...) o sentido da imagem de si, para si e para os outros" (Pollak, op. cit., p. 204; Thompson, 1998);

f) é possível verificar certa transferência de memória, tanto na projeção do presente sobre o passado (Hall, op. cit.), como na projeção de outros eventos sobre o evento rememorado ou projeção do grupo social sobre a lembrança individual, uma memória herdada (Pollak, op. cit.) ou reprimida e silenciada (Thompson, op. cit.); 
g) a memória resulta de "determinações sociais complexas", pois nós "pensamos, lembramos e exprimimo-nos em forma social e culturalmente determinada" (Hall, 1992, p. 157);

h) a memória não é, contudo, a expressão da essência dos grupos sociais (Pollack, 1992), pois se trata de um fenômeno concebido como uma construção feita em torno de conflitos e disputas;

i) a relação de suposta neutralidade e/ou passividade entre pesquisador e depoente (Portelli, 1997b);

j) o risco de “(...) transformar tudo em mera subjetividade e a história apenas numa simples coleção de testemunhos e depoimentos" (Costa, 1988, p. 9).

Os pesquisadores de história oral têm superado essas questôes, tratando as fontes orais como documentos orais em sua especificidade, e não como documentos escritos ou iconográficos. Para Portelli (1997a, p. 31):

A primeira coisa que torna a história oral diferente é aquela que nos conta menos sobre eventos que sobre significados. (...) Mas o único e precioso elemento que as fontes orais têm sobre o historiador, e que nenhuma outra fonte possui em medida igual, é a subjetividade do expositor. (...) Fontes orais contam-nos não apenas o que o povo fez, mas o que queria fazer, o que acreditava estar fazendo e o que agora pensa que fez. (Grifos do autor)

O que parecia fragilidade torna-se asserção. Portelli não descarta o uso de outras fontes ou a verificação da credibilidade factual do conteúdo dos relatos, como também não invalida as informações emitidas pelo depoente, sua visão dos fatos, seus anseios, suas frustrações, representaçōes que possuem significado para o entrevistado, pois produziram ações e inércia, dores e alegrias, sonhos e descrenças. Tal enfoque coaduna-se com a proposta e a perspectiva de trabalho aqui adotadas, pois não houve a pretensão e expectativa de encontrar verdades factuais em depoimentos absolutamente objetivos, mas sim de analisar as representações de professores de História acerca da dimensão utópica que transparece em sua visão de história, sobre sua própria prática e sobre sua disciplina, através de seus relatos. 
Dimensão utópica nas representações sobre o ensino de História...

O tratamento da temática aqui apresentada requereu a escolha de períodos passíveis de serem pesquisados, que pudessem ser reveladores de intenções e práticas mais significativas e bem delineadas, de modo a tornar possível a percepção e análise de sua formação e transformação.

Dessa maneira, pesquisei professores de História $^{3}$ de duas gerações em que as posições sobre esses aspectos fossem mais evidentes; dois grupos de professores de períodos distintos em que a questão da utopia se apresentasse de maneira diferenciada: professores que lecionaram entre os anos de 1965-1975 e 1985-1995. Os professores do primeiro grupo vivenciaram a experiência do regime militar. Observa-se nesse período o acirramento de posiçóes em setores do professorado e a identificação de certa dimensão utópica configurada em uma militância contrária à ditadura (Almeida Neto, 1996). Já os professores do segundo grupo passaram pela ditadura como alunos, sofrendo seus reveses de maneira menos direta, tendo começado a lecionar ao final do regime militar ou início da chamada redemocratização. Entretanto, respiraram resquícios de ares do autoritarismo e herdaram as mazelas provocadas pelos governos militares. Soma-se ao segundo grupo o fato de terem sido alunos dos professores da geração anterior, no $1^{\circ}$ e $2^{\circ}$ graus e graduação, passando a lecionar no período identificado como o da crise e falência das utopias.

Ao relatarem suas lembranças, os professores narraram sua trajetória pessoal e profissional, discorreram representaçóes sobre seu próprio processo de formação e transformação, como chegaram ao que são hoje, suas vitórias e derrotas, conquistas e decepções. Esse exercício da memória constituiu-se em verdadeira tomada de posição frente aos outros e a si mesmos, na medida em que falavam de seu devir, de seu próprio processo de vir a ser.

Nesses relatos, direta ou indiretamente, se apresentaram a maneira como os professores representam a história e seu ensino, a visão da história como uma espécie de fornecedora de exemplos a serem seguidos, sejam eles cívicos ou de militância política, a história doutrinária, conscientizadora ou crítica. Da mesma forma, ocorreram as representações sobre a prática escolar, lecionando história, implementando e participando de atividades, arriscando novos métodos e técnicas de ensino, organizando projetos, relacionando-se com colegas, alunos e direção. 
Compreender essas representações - sobre a história e seu ensino e sobre a própria prática - possibilita o entendimento daquilo que os professores fizeram ou julgavam fazer, fazem ou julgam que fazem e, ainda, o que julgam que fizeram, uma vez que são relatos do presente sobre o passado. Nessa busca, observam-se os desejos de mudanças, as promessas do novo contidas em seus projetos e como representam esses processos de mudança, a dimensão utópica que se manifesta no ensino de História - provocando e estimulando, bloqueando e inibindo -, em representações que se formam, transformam, desaparecem, agregam novas ideias e assimilam novas formas. O possível e o impossível, o lugar e o não-lugar, a existência e a busca, a presença e a ausência. A dimensão utópica nas representações sobre o ensino de História manifesta-se como incompletudes, projetando desejos à procura de realização e plenitude, revelando nuanças e uma complexa densidade.

Através de seus relatos, observam-se os mecanismos da memória a buscar no passado as realizaçôes, o tempo dos bons alunos, melhores relações profissionais e salários, mais respeito e interesse. Independente da idade dos professores, sempre há um tempo em que as irrealizações se projetam na busca de identidade e justificativas. É certo que os professores mais velhos, já aposentados e distantes da rotina escolar, tendem a idealizar um pouco mais esse tempo memorável, justamente por estarem afastados da lida diária e impossibilitados de novas realizaçóes nesse campo. Contudo, a busca dessa legitimidade do passado apresenta-se nos dois grupos de professores, já que, como aponta Thompson (1998, p. 289), “(...) a recordação é uma parte importante do processo de afirmação pessoal e pública do valor de uma vida”.

Entre as diversas lembranças dos "bons tempos", os professores sugerem a existência de melhores alunos: mais bem preparados, mais interessados e esforçados, respeitosos. No presente estão os semialfabetizados, fracos e desinteressados. Dependendo de quem lembra, aqueles "bons" alunos são os dos anos de 1960, 70 ou 80, falando inglês ou francês, lendo muitos livros, interessando-se e envolvendo-se com as questões políticas, participando das atividades intra e extraclasse. Também os professores desse tempo paradisíaco eram mais cultos, éticos, patriotas e politizados, implementando projetos, em comparação aos do presente, que seriam cínicos ou iludidos quanto à sua prática, sectários ou sem compromisso. 
Dimensão utópica nas representações sobre o ensino de História...

Esses professores e alunos eram projetados em outra escola, igualmente melhor, onde havia prazer em trabalhar, participar de desfiles e festas juninas, lavar banheiro e varrer o pátio. Havia bibliotecas que eram utilizadas e bons livros que eram lidos. Nessas escolas, os professores entrevistados tiveram grande atuação, fizeram projetos, deram suas melhores aulas e formaram os melhores alunos.

Também neste passado - situado no final da década de 1970, 1980 ou nos anos de 1990, dependendo de quem relata - estão as atuações políticas, que não se igualam às do presente. Reunião com ministros de Estado, ${ }^{4}$ manifestação contra a ditadura militar, atos de repúdio aos EUA, recepção ao líder sandinista Daniel Ortega, manifestações por eleições diretas, panfletagem e pichação. Os professores, cada qual com suas características e convicções políticas, viveram intensamente esses momentos. E ainda que não tenham participado diretamente, podem dizer, sobranceiros, que viveram "naquela época".

Importa, dados o propósito da pesquisa e a natureza da fonte documental, mais os significados que os elementos factuais dessas lembranças, revelando não só a dimensão utópica naquele passado, mas também as projeçóes do presente que por ora se manifesta perverso e frágil. Guardadas as diferenças entre os professores - relativas à idade, formação, atuação política, situação socioeconômica, leituras, relações que estabeleceu -, que se desdobram em representações, observamos um anseio, mais ou menos manifesto, de retorno, de volta a algo que se perdeu.

Ricouer, na série de aulas que ministrou na Universidade de Chicago, em 1975, reunidas no livro Ideologia e utopia, afirma, comentando a utopia de Fourier:

O tom religioso das proclamações de Fourier levanta uma questão acerca da utopia no seu todo: até que ponto o futurismo da utopia é fundamentalmente um regresso? Fourier comenta com muita frequência que aquilo que advoga não é reforma, mas um regresso, um regresso à raiz. Tem muitas páginas sobre o tópico do esquecimento. (...) esquecemos qualquer coisa e, consequentemente, o nosso problema não é tanto inventar como redescobrir o que esquecemos. (1986, p. 498)

A análise dos relatos dos professores demonstra a existência desse desejo utópico, cada qual com suas particularidades, de retornar a 
algo que se perdeu, algo que, em suas representações atuais, no exercício da memória, foi melhor; um tempo em que o ensino funcionava de modo eficiente e a disciplina de História cumpria seus propósitos. Essas representações apresentam-se como uma perspectiva utópica que, embora se projete para o futuro, deseja que se recupere uma espécie de elo perdido do passado.

Em alguns professores, notadamente os mais idosos, o desejo manifesto é a restauração desse passado, um projeto de futuro que reconstitua e conserve o passado. $\mathrm{Na}$ mesma obra, agora discutindo Mannheim, que elaborou uma tipologia das utopias, Ricouer (op. cit., p. 453 e 458) aponta que esse autor, a partir da noção de contra-utopia, catalogou o

(...) conservadorismo como uma utopia, o que, regra geral, é muito questionável. Segundo os seus três critérios, contudo, desde que tenhamos presente no conservadorismo uma forma que estrutura a vida, se apresenta incongruente e inclui um desejo dominante, então se trata de uma utopia. Mesmo que o conservadorismo seja um projeto para que o futuro restaure o passado, continua a ser uma utopia porque contraria outra utopia. (...) Quanto ao sentido de tempo do conservadorismo, é dada prioridade ao passado, não ao passado como abolido, mas ao passado que nutra o presente, dando-lhe raízes. Há uma noção de tradição, uma asserção de que algo é transmitido e continua vivo e de que o presente sem este efluxo subterrâneo seria vazio.

Nesses professores, seja pela idade ou por sua trajetória profissional, habita um passado congelado que foi cindido pelo total desligamento das lides escolares, eventualmente de maneira traumática, devido a sua absoluta perda de identificação com a instituição, professores e alunos, ou quando a crise da escola pública mostrou-se irreversível, ao final da ditadura militar, findando o patriotismo vivaz e atuante. Diante do presente sombrio, resta voltar-se para um passado seguro, sonhando com sua regeneração.

Em se tratando do ensino de História, essa visão prospectiva que acena para o passado e intenta um regresso à raiz, àquilo que se perdeu, e sua regeneração, resulta em lecionar com o intuito de retomar um passado para conservá-lo. Mesmo a visão supostamente mais crítica de alguns professores pode apontar para o conservadorismo, prevendo o retorno a esse passado idealizado, procurando exemplos que demonstrem 
Dimensão utópica nas representações sobre o ensino de História...

e justifiquem a necessária reconstituição das formas de luta que se deseja regenerar. Em alguns casos, o retorno pretendido sequer se projeta sobre um período efetivamente vivido, mas sobre um passado que, no terreno contestado da memória, ficou como uma herança mnemônica do grupo ao qual se pertenceu.

Nesse sentido, perde-se a dimensão de seu próprio tempo com suas transformaçōes, tornando o ensino de História não só uma mera fonte de registro dos acontecimentos do passado, mas mantendo vivo o desejo de retorno às raízes e conservação de tradições, como grande projeto de futuro.

Em outra face dessa mesma dimensão utópica, encontram-se as representações que miram o futuro com a pretensão não da restauração de algo que se perdeu, mas da transformação do presente com suas heranças do passado, de modo a inaugurar algo novo, rompendo com uma tradição, identificada no ensino de História como permanências: desigualdades sociais, concentração de renda e fundiária, miséria, oligarquias regionais, dependência econômica, corrupção.

O "professor crítico" investe contra esse modelo, dando ao ensino de História um caráter de luta, um combate cuja arma é fornecida em sala de aula: a "consciência crítica". Esse atributo é produzido de diferentes maneiras, atestam os professores, como a leitura de clássicos, textos engajados, músicas de protesto e leitura de jornal, mas também desfiles cívicos, festas juninas, eleições do Centro Cívico Escolar, passeatas e manifestações. Diversas formas de se adquirir consciência revelam diferentes entendimentos do que seja "consciência crítica". Nos relatos dos professores, esta consciência aparece associada à capacidade de participação política pelas vias institucionais ou pela sublevação às mesmas, identificação dos problemas socioeconômicos, desconfiança e questionamento, patriotismo e civismo, não se deixar induzir e seduzir pela mídia. Nota-se que a linha que separa a visão de conservação da de ruptura é muito tênue, gerando certa dificuldade para se definir claramente o perfil de cada professor. Ou, por outro lado, simplesmente não haja perfis estanques e delineados a serem identificados segundo o critério "isso ou aquilo".

$\mathrm{O}$ intento de conscientizar os alunos, infundindo-lhes capacidade crítica, tem sido um dos propósitos da pedagogia "moderna". Afirma Silva (1999, p. 111-112) que a 
(...) educação tal como a conhecemos hoje é a instituição moderna por excelência. Seu objetivo consiste em transmitir o conhecimento científico, em formar um ser humano supostamente racional e autônomo e em moldar o cidadão e a cidadã da moderna democracia representativa. É através desse sujeito racional, autônomo e democrático que se pode chegar ao ideal moderno de uma sociedade racional, progressista e democrática.

Independente da perspectiva utópica conservadora ou transformadora, a intenção de conscientizar através do ensino da História é um elemento fundamental das justificativas dos professores acerca da importância da disciplina.

Na tipologia de Mannheim, analisada por Ricouer, aparece o que ele chama de utopia humanitária liberal, baseada “(...) principalmente numa confiança no poder do pensamento como processo informativo e educativo", uma ideia capaz de mudar a ordem existente. Para Ricouer (1986, p. 456-457), esta “(...) forma é utópica na medida em que nega, e por vezes muito ingenuamente, as fontes reais do poder na propriedade, no dinheiro, na violência e em todos os tipos de forças nãointelectuais. Dá exagerada ênfase ao poder da inteligência para formar e moldar".

Os professores têm incorporado esse papel, definido mais claramente com o Iluminismo no século XVIII, o que pode ser percebido nitidamente pela declaração de intenções para o ensino de História, fornecida quando da realização das entrevistas: formar cidadãos, militantes, patriotas, críticos, conscientes, não sectários. Ricouer (op. cit. p. 485) observa, ainda, na visão utópica de Saint-Simon, a existência do professor-político ou educador-político, alguém que faz a mediação intelectual, alguém que inicia uma "reação em cadeia" capaz de promover as transformações. Essas imagens parecem familiares aos professores, particularmente os de História, dada a natureza política de sua disciplina: um professor, educador-político, que ilumina a inteligência, formando e moldando, instigando a reação em cadeia que transformará a sociedade.

Ocorre que, em oposição ao plano da modernidade e sua intenção crítica, ergueu-se o discurso pós-moderno, que, por “(...) considerar a consciência como sempre parcial, fragmentada e incompleta, (...) rejeita a ideia de educação como conscientização, como substituição de 
uma consciência ingênua por uma consciência crítica” (Moreira, 1997, p. 17). Dessa forma, os princípios fundantes da educação, da escola, do ensino, são postos sob suspeição, não restando pedra sobre pedra. Os projetos emancipadores e libertadores são vistos com ressalvas, pois convergiriam para os anseios de controle. Lembra Silva (1999, p. 115) que o "(...) pós-modernismo desconfia profundamente dos impulsos emancipadores e libertadores da pedagogia crítica. Em última análise, na origem desses impulsos está a mesma vontade de domínio e controle da epistemologia moderna”.

Afora as incongruências do debate, pode-se afirmar que, como características gerais, os postulantes do pós-modernismo questionam os pressupostos de razão, da ciência, da racionalidade e progresso constante das bases em que vem se erguendo a sociedade desde a renascença, consolidando-se com o Iluminismo (idem, ibid., p. 111). Tal posicionamento atacou frontalmente a perspectiva utópica, que tinha estes princípios por base. $\mathrm{O}$ anjo da história ficou imóvel, pasmado em sua inépcia.

$\mathrm{O}$ castelo argumentativo, tradicionalmente erguido pelos professores para justificar o ensino de História, parece ruir e o eco das vozes ainda pode ser ouvido nos relatos coletados: "estou meio perdida", "estou cansada", "era mais fácil ter certezas", "não tenho certeza de nada”, "tenho pensado em parar", "hoje é muito desgastante", "não saberia mudar", "qual é o nosso verdadeiro papel?", "a perspectiva não é lá muito agradável", "hoje em dia eu não me posiciono", "não vejo perspectiva de mudar", "está muito vazio".

Ocorre que, entre um modelo que se desfaz e outro que se constitui, os professores têm de se haver com seu cotidiano, vivenciando problemas concretos e concebendo proposições e alternativas. Em suas representações, observamos uma dimensão utópica que se mantém, via de regra, no registro da modernidade, ainda que como slogan, retórica vazia, herança de um modelo falido ou como forma de sentir-se atuante, militante, agente transformador, ainda que de maneira oca, sem maior substância.

\section{Considerações finais}

As representações dos professores acerca de sua disciplina e os diversos aspectos que a envolvem, entre eles a dimensão utópica, formam-se 
no permeio de sua vivência profissional e de como a concebem. Através dos relatos, observou-se que a intenção manifesta de "conscientizar" ou "formar o aluno crítico" forma-se na vivência, seja durante o curso de graduação com suas disciplinas voltadas para a prática do ensino, seja no cotidiano escolar, em suas várias instâncias, trocando informaçôes com os colegas, relacionando-se com os alunos, reuniōes pedagógicas, leituras, atividades sindicais, manifestações. Torna-se professor de História sendo professor de História, representando, projetando, desejando. Lefebvre (1983, p. 202-203) afirma que "No se puede decir que en general y abstractamente que la representación sirva o perjudique a la práctica. Se superpone a ella interpretándola; se inserta en ella. Lo que es indudable es que degenera o desvía (se desvía) cuando obstruye la práctica y mucho más aún cuando la práctica la paraliza o la vuelve ineficaz". É na vivência, portanto, que se formam as representações acerca da utopia no ensino de História - estimulando ações e aspirações -, mas também da impossibilidade de transformação e imobilismo.

Os mesmos relatos que afirmaram atuação para a conscientização e formação crítica revelaram desolação com as possibilidades da educação e do ensino de História. Crise de valores, professores mal formados, alunos semialfabetizados e desinteressados surgem nos relatos dos professores que ainda estão na ativa como num retorno aos problemas apontados pelos mais velhos, quando estavam se aposentando, sugerindo que os problemas atuais são continuidade daqueles observados nos anos de 1970 e 1980, tornando-os obstáculos intransponíveis. Mesmo o professor que, bradando seu engajamento político, preocupa-se em dissipar o pensamento fatalista dos alunos acaba sendo vítima do próprio engenho, pois incorre em outra fatalidade: a luta política trará a superação inevitável dos problemas combatidos, pois é assim que funciona em seus exemplos do passado. Contudo, a não superação e a permanência das mesmas questões vão gerando desconforto, frustração, cansaço de ser a "menina problema" que "derruba portas" todos os dias.

Essa espécie de desencantamento em relação à educação e ao ensino de História articula-se à discussão sobre os "fundamentos do mal-estar" na "sociedade burocrática de consumo dirigido", apontada por Lefebvre (1991, p. 68). Ele afirma que a satisfação no cotidiano moderno tornou-se o fim e a legitimação de nossa sociedade, de modo 
Dimensão utópica nas representações sobre o ensino de História...

a desenvolver a crença que nossas necessidades são ou serão satisfeitas, constituindo uma saturação:

A necessidade se compara a um vazio, mas bem definido, a um oco bem delimitado. O consumo e o consumidor enchem esse vazio, ocupam esse oco. É a saturação. Logo que atingida, a satisfação é solicitada pelos mesmos dispositivos que engendraram a saturação. Para que a necessidade se torne rentável, é estimulada de novo, mas de maneira um pouquinho diferente. As necessidades oscilam entre a satisfação e a insatisfação, provocadas pelas mesmas manipulações. (...) De fato e em verdade (mas quem o ignora?), faz-se acompanhar de uma crise generalizada dos "valores", das ideias, da filosofia, da arte, da cultura. $\mathrm{O}$ sentido desaparece de outra forma: há um vazio enorme, o vazio de sentido, que nada vem encher, a não ser a retórica. (p. 89)

Nos relatos analisados, observa-se como essa busca da satisfação tem alimentado os professores, nesse caso os de História. As representaçôes acerca de seu poder conscientizador, de que seriam dotados de uma capacidade de ver o que tem por "detrás dos acontecimentos", de compreensão da verdade e, portanto, uma figura-chave nos processos de transformação, geram uma perspectiva de "satisfação" que, no cotidiano escolar, envolvido com os problemas imediatos, simplesmente não se desenvolve, não acontece, gerando frustração e mal estar. Pode-se dizer que a existência de certo desencantamento, ou esvaziamento, com a dimensão utópica no ensino de História está nessa efemeridade e descartabilidade do desejo, sua rápida satisfação/insatisfação.

Por outro lado, ainda na ânsia de satisfação, o professor embarca em diversos "projetos" e atividades, às vezes desconexos, que se configuram em um ativismo desprovido de maior sentido e que, supostamente, logrará resultados rápidos ao final do processo, mas que logo provocarão nova insatisfação ou saturação, engendrando novos projetos e mal estar, representaçôes a obstruir a prática. Não é tanto o ensino militante, engajado e utópico que importa ao professor, mas as representaçōes sobre o ato educativo, que acabam por banalizar a crítica. Passa a ser mais importante sentir-se um "agente transformador", cumprindo seu "papel" na sociedade e na escola, "conscientizando" seus alunos com o ensino de História "crítico". Constituem-se, assim, representaçóes dissimuladoras que deslocam e manipulam o real, representações enganosas que resultam em repetições e situações miméticas, que 
acabam por suprimir as reais possibilidades de ações transformadoras no cotidiano, tanto escolar como social, promovendo, ao invés disso, simulacros que provocam o aprisionamento dos indivíduos no terreno estéril das ausências.

Qual o "alvo" das propostas utópicas dos professores? Contra quem investem em suas representações? Contra o quê investem? O que querem? Há que se saber o que se quer. E o que se lamenta. As representações, deslocando e substituindo a presença na ausência, podem propender à alienação e à repetição (Lefebvre, 1983), tornando o ensino de História um mero registro conservador do passado - ainda que declare o contrário - ou imbuído de uma crítica oca.

Afora o desencanto registrado - ausências vividas como decepções - e a vontade manifesta de transformar - ações pensadas como presença -, a dimensão utópica parece se restabelecer em outro nível, revelando outro desejo que se desloca entre o anseio de conscientização e denúncia, iluminação e militância, indignação e crítica: a própria poiesis, a criação, a formação, o ato criativo. A utopia nas representações analisadas aponta para uma percepção, ainda que a duras penas, de que a "consciência crítica" não se dá por imposição. A dimensão utópica que se revela é a da transmissão do desejo de querer transformar. A utopia transmutou-se em anseio de passar adiante o próprio desejo de busca.

\section{Recebido em janeiro de 2008 e aprovado em abril de 2008.}

\section{Notas}

1. Utilizei “H” maiúsculo para me referir à disciplina escolar.

2. Esse artigo é um desdobramento de minha tese de doutorado, intitulada "Dimensão utópica nas representações sobre o ensino de História: memórias de professores”.

3. Foram entrevistadas seis professoras de diferentes faixas etárias, formação acadêmica, atuação política e profissional.

4. Informações constantes nos relatos fornecidos pelos professores entrevistados.

5. Assim se autodefiniu, de maneira contundente, uma das professoras entrevistadas: "Tenho muita paixão, por isso que eu sofro muito dentro da escola, eu vivo me batendo, eu me bato muito, muito, muito, muito. Não tem um dia em que eu não derrube uma porta, disso eu estou cansada, de ser a moça problema, a que está sempre insatisfeita”. 


\section{Referências}

ALMEIDA NETO, A.S. O ensino de História no período militar: práticas e cultura escolar. 1996. 216p. Dissertação (Mestrado em Didática) - Faculdade de Educação, Universidade de São Paulo, São Paulo.

ALMEIDA NETO, A.S. Dimensão utópica nas representaçôes sobre o ensino de História: memórias de professores. 2002. 310p. Tese (Doutorado em Historiografia e História da Educação) - Faculdade de Educação, Universidade de São Paulo, São Paulo.

BENJAMIN, W. Magia e técnica, arte e política. São Paulo: Brasiliense, 1986.

COSTA, E.V. História, metáfora e memória: a revoltas de escravos de 1823 em Demerara. São Paulo: Arquivo e História, 1988.

HALL, M.M. História oral: os riscos da inocência. In: O DIREITO à memória. São Paulo: Secretaria Municipal de Cultura; Departamento do Patrimônio Histórico, 1992. p. 151-160.

HOBSBAWM, E. Sobre história. São Paulo: Cia. das Letras, 1998.

JANOTTI, M.L.M.; ROSA, Z.P. História oral: uma utopia? Revista Brasileira de História, São Paulo, v. 13, n. 25/26, p. 7-16, set. 1992/ ago. 1993.

LAVILLE, C. A guerra das narrativas: debates e ilusões em torno do ensino de História. Revista Brasileira de História, São Paulo, v. 19, n. 38, p. 125-138, 1999.

LEFEBVRE, H. La presencia y la ausencia: contribuición a la teoria de las representaciones. México: Fondo de Cultura Económica, 1983.

LEFEBVRE, H. A vida cotidiana no mundo moderno. São Paulo: Ática, 1991.

LUTFI, E.P.; SOCHACZEWSKI, S.; JAHNEL, T.C. As representações e o possível. In: Martins, J.S. (Org.). Henri Lefebure e o retorno à dialética. São Paulo: Hucitec. 1996. p. 87-97. 
MOREIRA, A.F.B. Currículo, utopia e pós-modernidade. In: MoreirA, A.F.B. (Org.). Currículo: questões atuais. São Paulo: Papirus, 1997. p. 9-28.

POLLAK, M. Memória e identidade social. Estudos Históricos, Rio de Janeiro, v. 5, n. 10, p. 200-212, 1992.

PORTELli, A. O que faz a história oral diferente. Projeto Historia: Revista do Programa de Estudos Pós-Graduados em História, São Paulo, n. 14, p. 25-39, fev. 1997a.

PORTELLI, A. Forma e significado na história oral: a pesquisa como um experimento em igualdade. Projeto História: Revista do Programa de Estudos Pós-Graduados em História, São Paulo, n. 14, fev. 1997b.

RICOEUR, P. Ideologia e utopia. Lisboa: Edições 70, 1986.

SEVCENKO, N. O enigma pós-moderno. In: Oliveira, R.C. (Org.). Pós-modernidade. Campinas: UNICAMP, 1993. p. 43-55.

SILVA, T.T. Documentos de identidade: uma introdução às teorias do currículo. Belo Horizonte: Autêntica. 1999.

SOARES, M.B. Metamemória - memórias: travessia de uma educadora. São Paulo: Cortez, 1991.

THOMPSON, A. Quando a memória é um campo de batalha: envolvimentos pessoais e políticos com o passado do Exército nacional. Projeto História: Revista do Programa de Estudos Pós-Graduados em História, São Paulo, n. 16, fev. 1998. 